\title{
DNA Damage and Repair in Schizophrenia and Autism: Implications for Cancer Comorbidity and Beyond
}

\author{
Enni Markkanen ${ }^{1, *}$, Urs Meyer ${ }^{1}$ and Grigory L. Dianov ${ }^{2,3}$ \\ 1 Institute of Pharmacology and Toxicology, Vetsuisse Faculty, University of Zürich, Winterthurerstrasse 260, \\ Zürich 8057, Switzerland; urs.meyer@vetpharm.uzh.ch \\ 2 Cancer Research UK and Medical Research Council Oxford Institute for Radiation Oncology, \\ Department of Oncology, University of Oxford, Oxford OX3 7DQ, UK; grigory.dianov@oncology.ox.ac.uk \\ 3 Institute of Cytology and Genetics, Russian Academy of Sciences, Lavrentyeva 10, \\ Novosibirsk 630090, Russia \\ * Correspondence: enni.markkanen@vetpharm.uzh.ch; Tel.: +41-44-635-8770
}

Academic Editor: Guillermo T. Sáez

Received: 15 April 2016; Accepted: 27 May 2016; Published: 1 June 2016

\begin{abstract}
Schizophrenia and autism spectrum disorder (ASD) are multi-factorial and multi-symptomatic psychiatric disorders, each affecting $0.5 \%-1 \%$ of the population worldwide. Both are characterized by impairments in cognitive functions, emotions and behaviour, and they undermine basic human processes of perception and judgment. Despite decades of extensive research, the aetiologies of schizophrenia and ASD are still poorly understood and remain a significant challenge to clinicians and scientists alike. Adding to this unsatisfactory situation, patients with schizophrenia or ASD often develop a variety of peripheral and systemic disturbances, one prominent example of which is cancer, which shows a direct (but sometimes inverse) comorbidity in people affected with schizophrenia and ASD. Cancer is a disease characterized by uncontrolled proliferation of cells, the molecular origin of which derives from mutations of a cell's DNA sequence. To counteract such mutations and repair damaged DNA, cells are equipped with intricate DNA repair pathways. Oxidative stress, oxidative DNA damage, and deficient repair of oxidative DNA lesions repair have been proposed to contribute to the development of schizophrenia and ASD. In this article, we summarize the current evidence of cancer comorbidity in these brain disorders and discuss the putative roles of oxidative stress, DNA damage and DNA repair in the aetiopathology of schizophrenia and ASD.
\end{abstract}

Keywords: DNA base excision repair; XRCC1; neurodevelopmental disorders; oxidative DNA damage; oxidative stress; autism; schizophrenia; cancer

\section{Schizophrenia and Autism Spectrum Disorder: Symptoms and Origins}

Schizophrenia and autism spectrum disorder (ASD) are multi-factorial and multi-symptomatic psychiatric disorders, each affecting $0.5 \%-1 \%$ of the population worldwide [1,2]. Both are characterized by impairments in cognitive functions, emotions and behaviour, and they undermine basic human processes of perception and judgment $[2,3]$. In view of their chronicity and severity, schizophrenia and ASD impose tremendous mental and economic burdens on the affected individuals, and in turn, on their families and society in general $[4,5]$.

Typically, the onset of full-blown schizophrenia is in early adulthood and includes a myriad of symptoms, which are commonly referred to as positive, negative and cognitive symptoms [2]. Positive symptoms are pathologies that do not present in healthy individuals but are a result of the disease process. These include visual and/or auditory hallucinations, delusions, paranoia, and psychomotor 
agitation. Negative symptoms refer to physiological features that are reduced or absent as a result of the disease process, including social withdrawal, apathy, deficits in motivation and reward-related functions, and alogia. Cognitive symptoms of schizophrenia involve deficits in executive functions, working memory, and attention, which in turn can undermine reasoning, planning and problem solving in affected individuals.

ASD is characterized, to a varying degree, by severe deficiencies in social interaction, a lack of verbal and nonverbal communication, and the presence of restricted and repetitive behaviours [3]. Initially, ASD was sub-categorized into autism, Asperger syndrome, pervasive developmental disorder-not otherwise specified (PDD-NOS), and childhood disintegrative disorder [1,3]. These subtypes seemed to differ primarily in the nature and/or severity of cognitive delay and the presence of intellectual disability. Individuals with Asperger syndrome generally lack delays in cognitive development and communication, in contrast to autism. With the release of the 5th Diagnostic and Statistical Manual of Mental Disorders (DSM-5), however, all subtypes were merged into one umbrella diagnosis of ASD [6]. Overt symptoms of ASD can begin as early as by the age of six months, become established by two to three years, and tend to persist throughout life [1,3,7-10].

Interestingly, schizophrenia and ASD seem to overlap at multiple levels. For example, disruption of emotional processing and sensorimotor gating, and impairments in executive functions, are psychopathological features commonly observed in both disorders [3,11-16]. Furthermore, patients with schizophrenia and ASD display a similar pattern of deficient neuronal activation during a social cognition task, with both patient groups showing reduced activation in the right amygdala, fusiform gyrus, and ventrolateral prefrontal cortex [17-22]. The impression of overlapping brain abnormalities between schizophrenia and ASD has also been supported by meta-analytic anatomical likelihood estimations consolidating multiple imaging datasets, which reveal appreciable brain structural concordance between the two disorders, especially in the right parahippocampal gyrus, posterior cingulate, putamen, claustrum and left thalamus $[13,17,21,23]$. Finally, the neuropathology of schizophrenia and ASD also overlap at the cellular levels. One example relates to the imbalances in excitatory versus inhibitory neurotransmission, which involve disturbances in glutamate and $\gamma$-aminobutyric acid (GABA) signalling and leads to increased excitatory-inhibitory ratios in both disorders $[7,8,10,19-21]$.

Despite decades of extensive research, the aetiologies of schizophrenia and ASD are still poorly understood and remain a significant challenge to clinicians and scientists alike. According to the prevailing view, both disorders involve changes in early brain development and subsequent brain maturation [11,12,14-16,24]. Hence, an interaction between foetal neurodevelopmental disturbances and changes in postnatal brain maturation seems necessary to trigger the onset of full-blown psychotic or autistic disorders. Within this neurodevelopmental framework, the combined action of multiple genes (of small effect size) and a number of environmental risk factors is required to cause schizophrenia and ASD [17,19-22,25]. According to such gene-environment interaction models, the effect of an individual's genotype depends on environmental exposure and, vice versa, the effect of environmental exposure on risk depends on an individual's genotype $[17,21,23,26,27]$. Recent advances in genome-wide association studies (GWAS) have generated reproducible findings on a number of common risk alleles in both schizophrenia and ASD [19-21,28,29]. However, the heritability estimates of the relative contribution of common genetic variants based on molecular genetic data appear to be considerably smaller [24,30] than heritability estimates from twin studies [25,31,32]. The discrepancy between heritability estimates from twin and molecular genetic studies may emerge because gene-environment interactions involving shared environmental factors within families are included in heritability estimates of twin studies, but not in molecular genetic studies of unrelated subjects $[26,27,33]$. The comparison between monozygotic and dizygotic twins allows, to a certain extent, an estimation of the relative contribution of genetic versus environmental factors, and consequently, twin studies can readily take into account gene-environment interactions in their heritability estimates. Indeed, it is the general consensus that differences between monozygotic 
twins are primarily attributable to the environment, whereas differences between dizygotic twins to both hereditary and environmental factors in twin studies [34]. According to several lines of evidence, however, deducing the contribution of genetic factors in twin studies may be misleading, partly because the prenatal environment (and its interaction with genetic predisposing factors) is rarely dealt with adequately [35-37]. For example, the majority of monozygotic twins are monochorionic. Hence, many monozygotic twins share the same placenta, whereas all dizygotic twins are dichorionic [38]. Given that normal placental functions are essential for proper foetal development, including brain development [39], neurodevelopmental abnormalities arising from placental dysfunctions in monochorionic twins may be misinterpreted as being of genetic origin.

The further elucidation of aetiological mechanisms in schizophrenia and ASD also appears crucial with regards to the need of more effective treatments. In schizophrenia, pharmacotherapy with currently available antipsychotic drugs can only partially normalize psychopathological symptoms and are particularly poor in alleviate negative and cognitive symptoms $[28,29,40]$. Similarly, there are still no effective treatments against ASD-related symptoms such as social interaction and communication deficits [30,41].

Adding to this unsatisfactory situation, patients with schizophrenia or ASD often develop a variety of peripheral and systemic disturbances, some of which are clinically highly relevant and can further undermine the daily life quality of the affected individuals [31,32,42,43]. One prominent example is cancer, which shows a direct (but sometimes inverse) comorbidity in people affected with neurodevelopmental disorders such as schizophrenia and ASD [33,44-47]. In this article, we summarize the current evidence of cancer comorbidity in these brain disorders and discuss the putative role of DNA damage in this context.

\section{Schizophrenia, Autism Spectrum Disorder and Cancer Risk}

The hypothesis of altered cancer risk in schizophrenia is not new, yet it still appears conflicting, as reviewed in $[40,41]$. For example, early studies by Mortensen $[42,43,48]$ showed that the overall incidence of cancer was lower for male (but not female) patients with schizophrenia as compared to the general population. A similar reduction in overall cancer risk has also been demonstrated in several subsequent studies (e.g., [44-47,49,50]. Interestingly, Ji et al. $[47,51])$ reported that the overall cancer risk was not only lower in patients, but also significantly reduced among their unaffected parents and siblings, suggesting the involvement of genetic factors in this association. A similar finding was provided by Catts et al. [47,52], who found reduced cancer risk in unaffected first-degree relatives of patient with schizophrenia.

These findings suggesting reduced cancer risk in schizophrenia contrast with other epidemiological reports demonstrating no changes or even increased risk of developing cancer in schizophrenia. For example, some reports show increased overall cancer risk in patients with schizophrenia $[48,53,54]$ or a higher risk for specific cancers such as colon, breast and stomach cancers $[49,50,55,56]$. Increased cancer risk was also found in the study by Lin $e t$ al., who demonstrated that this association is restricted to female patients with schizophrenia and inversely correlate with the age of schizophrenia onset [51,52]. Marked sex differences were also obtained in the study by Ji et al., suggesting that female schizophrenic patients have a higher cancer risk than the general population for breast, cervical and endometrial cancers $[47,48]$.

Hence, the extent to which schizophrenia is associated with altered cancer risk remains controversial (e.g., reviewed in $[33,53,54,57])$. One reason for these conflicting findings may be the varying contribution of environmental factors such as smoking habits, nulliparity, obesity and exposure to antipsychotics $[55,56,58]$. Indeed, adjustments for possible confounding factors such as smoking can markedly change the magnitude or even the direction of cancer risk. For example, Catts et al. found that schizophrenia is associated with a modest but significant increase in lung cancer risk in unadjusted analyses [52,59-62]. When adjusted for smoking, however, patients with schizophrenia tend to show decreased lung cancer risk. Similarly, Lichtermann et al. found that patients with schizophrenia 
display an increased overall cancer risk, whereas cancer risk is consistently lower in their unaffected first-degree relatives. These diametrically opposite effects may readily be explained by the varying contribution of specific lifestyle factors such as excessive smoking and alcohol consumption, which are more prevalent in patients with schizophrenia as compared to non-affected individuals $[33,48,57]$.

In contrast to schizophrenia, only a few studies have estimated cancer risk in ASD. The available data suggest, however, that ASD is generally associated with increased cancer risk. For example, ovarian cancers and central nervous system (CNS) cancers such as neurofibromatosis are more prevalent in ASD subjects as compared to non-ASD subjects $[33,57,63]$. There is also initial evidence suggesting that ASD is associated with increased breast cancer risk [58,64]. Interestingly, recent genome-wide exome sequencing has revealed extensive overlap in risk genes for ASD and for cancer [59-63], suggesting that altered cancer risk in ASD subjects may have a strong genetic basis. Many of these genes have been implicated in pathophysiological processes underlying cancer development, including genes involved in DNA repair $[33,57,65]$. DNA repair is considered one of the foremost cellular defence mechanisms to counteract cancer formation, raising the possibility that changes in DNA repair and/or DNA damage might be a molecular link between altered cancer risk and neurodevelopmental disorders such as ASD and schizophrenia.

\section{DNA Damage, DNA Repair and Cancer}

Cancer is a disease characterized by the loss of control by the organism over a small subset of cells, which start to proliferate regardless of the borders imposed by the surrounding tissue. For this to occur, cancer cells have to acquire a subset of characteristics that ensures their survival and enables their growth despite adversary reactions from the surrounding. These features are collectively referred to as 'hallmarks of cancer' $[63,66]$.

The molecular origin of virtually all cancers derives from mutations of a cell's DNA sequence $[64,67,68]$. Indeed, genomic instability and mutation is recognized as one of the very few enabling characteristics that clearly drive cancer formation by facilitating the acquisition of all other core hallmarks of cancer $[63,65]$. Mutations can arise when the integrity of DNA is challenged by agents deriving from exogenous sources [65]. To counteract the formation of mutations, cells have evolved a plethora of DNA repair pathways that sense, report and correct alterations in DNA $[66,69,70]$. Deficiencies in some of these repair pathways have been implicated to act as key players in the induction and progression of cancer $[63,64,67,68]$. It is noteworthy, however, that even in the absence of exposure to damaging exogenous agents (such as ultraviolet (UV) radiation or tobacco smoke), DNA is a very sensitive molecule prone to undergo spontaneous alterations. These can be caused by DNA's chemical instability as well as many different intracellular (endogenous) mutagens that are present in the cell (reviewed in $[65,71]$ ). For instance, the need for oxygen to support all vital functions of a mammalian cell drives also the formation of a variety of reactive oxygen products, such as hydrogen peroxide, superoxide ions or hydroxyl radicals. These reactive oxygen species avidly react with macromolecules present in the cell, among which DNA presents a particularly vulnerable target. DNA is prone to undergo spontaneous alterations, caused by its chemical instability, as well as the presence of endogenous harmful agents, such as oxygen radicals (reviewed in $[65,68,72-76])$. Such insults lead to the formation of small base lesions and single-strand DNA breaks (SSBs), which are constantly undermining genomic integrity. Estimates of these lesions range from 10,000-20,000 for small base lesions up to 150,000 for SSBs generated in every single cell every single day under physiological, non-stressed conditions [69-71]. If left unrepaired, this type of damage can give rise to the formation of mutations in the DNA, which can ultimately lead to the onset of diseases such as cancer $[63,64,71,76,77]$.

There are multiple DNA different repair pathways that catalyse the reconstitution of DNA integrity when it has been compromised. Among them, base excision repair (BER) is one of the most important mechanisms to safeguard cells from the frequently occurring small DNA base lesions and SSBs $[71,73]$. BER acts like a housekeeper that constantly cleans away the multitude of different base lesions and SSBs, thus ensuring the maintenance of intact and unaltered double-stranded DNA, 
which in turn is pivotal for all physiological cellular functions. Taking into account the numbers of DNA lesions that BER has to correct even under physiological conditions, it follows that a decrease in BER repair capacity-either by changes in the protein sequence due to genetic polymorphisms, or changes in protein expression levels - can lead to an accumulation of DNA damage in the cells. Therefore, disruptions in DNA repair pathways can cause a change in DNA repair capacity of the affected cell or tissue that might manifest itself in increased levels of DNA damage. This readily predisposes cells to accumulating DNA damage, which in turn has been aetiologically linked to the development of a variety of human diseases, such as cancer, premature aging, and also neurodegenerative conditions like Alzheimer's disease and Parkinson's disease [68,71-76].

Classical BER of damaged DNA bases is initiated by damage-specific DNA glycosylases, which identify and excise the corrupted base by hydrolysis of the $\mathrm{N}$-glycosylic bond linking the DNA base to the sugar phosphate backbone (reviewed in [71,76], for details, see Figure 1). The phosphodiester bond $5^{\prime}$ to the resulting abasic site (AP-site) is cleaved by AP endonuclease 1 (APE1), thus generating a single strand DNA break with $5^{\prime}$-deoxyribose phosphate. Importantly, different classes of DNA glycosylases exist, and they differ in their mechanism to release the damaged base, resulting in a variety of intermediate products with chemically different termini (for details, see [71,76,77]). All these repair intermediates containing a variety of termini have to be further processed to yield $3^{\prime}-\mathrm{OH}$ and $5^{\prime}$-P residues flanking the 1-nucleotide gap, as these are prerequisite to allow DNA polymerisation and ligation of the ends. There are several end-processing enzymes in mammalian cells including APE1, polynucleotide kinase phosphatase (PNKP) and aprataxin, which removes blocking residues from $5^{\prime}$ - to $3^{\prime}$-DNA ends (reviewed in [71,73]). Further processing of this single strand break containing intermediate is carried out by a DNA repair complex that includes DNA polymerase $\beta$ ( $\operatorname{Pol} \beta$ ), X-ray repair cross-complementation group 1 (XRCC1) and DNA ligase IIIa (Lig III). Pol $\beta$ has a dRP-lyase activity that removes the $5^{\prime}$-sugar phosphate and also, functioning as a DNA polymerase, adds one nucleotide to the $3^{\prime}$-end of the single-nucleotide gap. Finally, the XRCC1-Lig III complex seals the DNA ends, therefore accomplishing DNA repair [71,73].

The enzymes of the BER pathway also repair DNA SSBs. SSBs arise from disintegration of oxidised deoxyribose, yielding a break in the DNA backbone while retaining all DNA bases. Very often, the termini resulting from such breaks are damaged, and thus need to be processed to give rise to $3^{\prime}-\mathrm{OH}$ and 5'-P DNA ends. This processing is performed by a variety of different enzymes, and the interested reader is referred to an excellent review on this subject [73,83]. After DNA end processing has been accomplished, the DNA ends are ligated back together by the Pol $\beta / \mathrm{XRCC} 1 / \mathrm{Lig} 3$ complex.

Several mutations in the BER-pathway have been associated with the development of cancer (reviewed in $[78,84]$ ). Most notably, defects in repair of one of the most abundant oxidative DNA lesion, 8-oxo-deoxyGuanine (8-oxo-G), are implicated in familial cancer syndromes involving mutations in the DNA glycosylases MutY homolog (MUTYH) or 8-oxoguanine DNA-glycosylase 1 (Ogg1). 8-oxo-G is a miscoding lesion that can lead to insertion of incorrect A opposite 8-oxo-G upon DNA replication, which therefore frequently leads to formation of an A:8-oxo-G base pair during DNA replication (reviewed in $[79,85]$ ). If left unrepaired, this mismatch can further propagate into a CG $\rightarrow A T$ transversion point mutation upon further replication. MUTYH is a DNA glycosylase that removes the A from A:8-oxo-G base pairs, thus paving the way for correction of the 8-oxo-G damage by a coordinated interplay of DNA polymerase $\lambda$, Ogg1 DNA glycosylase and the canonical BER pathway [80-82,86-88].

As mentioned above, cancer is a disease characterized by uncontrolled proliferation of cells. In view of the fact that ASD and schizophrenia are manifestations of neuronal cell dysfunction, how can a defect in a single gene possibly cause neuronal dysfunction-which per se is not characterized with increased cellular proliferation, as neuronal cells are postmitotic-while at the same time causing an defect in another tissue that gives rise to cancer? In an attempt to answer this, consider the following examples. 


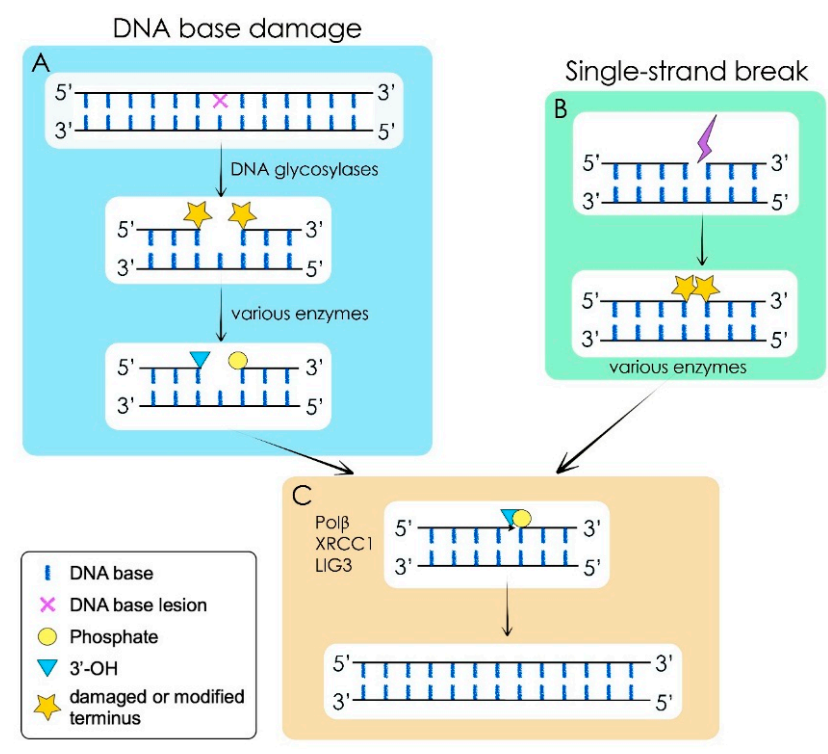

Figure 1. Simplified scheme of base excision repair (BER). Modified after [76,78]. (A) BER is initiated by damage-specific DNA glycosylases, which identify and release the corrupted base by hydrolysis of the $N$-glycosylic bond linking the DNA base to the sugar phosphate backbone (reviewed in $[76,79]$ ). The arising abasic (AP) site is further processed by AP-endonuclease 1 (APE1), and depending on the mechanism by which the DNA base was removed, end processing of the modified $3^{\prime}$ - and $5^{\prime}$-termini is performed by a variety of end-processing enzymes. This processing results in the generation of a $3^{\prime}-\mathrm{OH}$ and a 5'-P group adjacent to the DNA gap or break; (B) Single-strand breaks (SSBs) can also arise from direct disintegration of oxidised deoxyribose. This process usually leads to damaged or modified termini, which are processed by a variety of enzymes to $3^{\prime}-\mathrm{OH}$ and $5^{\prime}-\mathrm{P}$ groups. SSBs are then handled identically to the BER intermediates from this point onward; $(C)$ Further processing of the SSB containing intermediate stemming from either source is carried out by the core BER complex that includes DNA polymerase $\beta$ (Pol $\beta$ ), XRCC1 (X-ray repair cross-complementation group 1) and DNA ligase IIIa (Lig III). Pol $\beta$ possesses a dRP-lyase activity that removes the $5^{\prime}$-sugar phosphate and also, functioning as a DNA polymerase, adds one nucleotide to the $3^{\prime}$-end of the arising single-nucleotide gap. Finally, the XRCC1-Lig III complex seals the DNA ends, therefore accomplishing complete DNA repair [71,80-82].

Several genetic disorders demonstrate that changes in a single protein can have a multifaceted impact on the entire organism. Among the most prominent examples to illustrate that a defect in one gene product gives rise simultaneously to a variety of neurological as well as oncological disorders is Ataxia-Teleangiectasia (A-T). A-T is a rare autosomal recessive disorder caused by mutation of the gene A-T mutated (ATM), a serine-threonine protein kinase that orchestrates the response to cellular stress situations, such as DNA double-strand breaks (reviewed in [83]). A-T patients develop early-onset progressive cerebellar ataxia, oculocutaneous teleangiectasia, immunodeficiency, and have a high incidence of cancer, particularly lymphoid tumours. One of the main questions arising from these findings is, how can a gene defect cause cellular dysfunction in one tissue, while being accessory to the development of a proliferative malignancy in others? The main reason for this variegated phenotype is most likely based on cellular differences in the affected tissues, namely postmitotic neurons in the brain versus proliferative cells from the hematopoietic lineage in the case of lymphoid tumours. While genetic instability in postmitotic cells such as the brain manifest in cellular dysfunction, which then leads to clinical features of neurodegeneration due to the loss of neuronal tissue, in a cell with replicative potential it can lead to malignant transformation thus giving rise to cancer. Another very interesting example for how a decrease in neuronal function can be associated at the same time with an increased cancer risk are patients with Down syndrome (DS). In DS patients chromosome 21, or parts thereof, 
is present in triplicate, which clinically manifests in physical growth delays, intellectual disability, and a series of other disorders (reviewed in [84]). Moreover, DS patients exhibit a 10- to 20-fold higher risk for leukemia but markedly lower incidence of solid tumours (reviewed in [85]). The molecular basis behind these differences in cancer predisposition remain unclear to date, but the cell-type specific effect that is alluded to above could very well play an important determinant in the case of DS as well.

\section{Oxidative Stress, DNA Damage and DNA Repair in Schizophrenia and Autism Spectrum Disorder}

\subsection{Oxidative Stress, Mitochondrial Dysfunctions and DNA Damage}

As outlined above, DNA damage can either stem from exposure to exogenous DNA damaging agents, such as tobacco smoke or UV radiation, endogenous sources such as oxidative stress stemming from the respiratory chain, or it can be caused by a decrease in repair of normal levels of DNA damage constantly present in our genomes. Within the last decades, a plethora of findings have implicated oxidative stress and subsequent DNA damage in the development of schizophrenia and ASD. Indeed, signs of increased oxidative stress and oxidative DNA damage has been detected in various tissues of schizophrenic patients [86-107]. Additional evidence supporting a role of redox imbalances and oxidative stress in the development of schizophrenia stems from various animal models, which suggest that increased oxidative stress during sensitive windows of brain development and maturation is causally related to the subsequent emergence of schizophrenia-related brain and behavioral abnormalities [108-112].

Redox imbalances and oxidative stress in schizophrenia may further involve, or even be triggered by, functional deficits in the mitochondrial respiratory chain (reviewed in [108,113]). In support of this hypothesis, mitochondrial dysfunctions have been closely linked to the pathogenesis of schizophrenia and related psychotic disorders (reviewed in $[89,90,114,115]$ ). It still remains debatable, however, whether increased oxidative stress is the primary cause or rather a consequence of mitochondrial deficits. According to recent theories $[91,93,95,116]$, oxidative stress may not be primarily involved in generating mitochondrial DNA damage, but rather triggers a cellular stress response that in turn causes damage. It is also known that deletions in mitochondrial DNA increase as a function of age, especially in post-mitotic cells with high metabolic demands, such as the brain. Interestingly, however, post-mortem analyses of mitochondrial deletions revealed a significant decrease in the global accumulation of mitochondrial DNA deletions in patients with schizophrenia as compared to patients with major depressive disorder or bipolar, or compared to age-matched control subjects [108,117]. This decrease was largest in dopaminergic regions such as caudate nucleus, putamen and substantia nigra $[108,118]$. One interpretation of these findings is that schizophrenia is, for yet unknown reasons, associated with a primary deficit in mitochondrial functions, which in turn might lead to a decrease in mitochondrial metabolism and therefore result in reduced mitochondrial deletions.

Increased levels of oxidative stress and oxidative DNA damage have also been reported in ASD subjects, as well as in animal models relevant to this disorder $[114,115,119]$. Reduced ratios of reduced glutathione (GSH) to its oxidised form GSSG (glutathione disulfide), indicative of oxidative stress, along with decreased total GSH levels were found in the cerebellum and temporal cortex in ASD subjects, suggesting a deficit in the redox balancing system and the antioxidant defence mechanisms in affected individuals [116,120]. Decreased GSH:GSSG ratios along with increased levels of 8-oxo-G and other markers of oxidative stress were also detected in the cerebellum and Brodmann Area 22 of ASD subjects [117,121-123]. Moreover, oxidation damage to DNA and a deficit in antioxidant capacity was also found in plasma from children with ASD as compared to non-affected siblings [114,118,124].

Similar to schizophrenia, functional deficits in the mitochondrial respiratory chain may readily contribute to the emergence of increased oxidative stress in ASD. In support of this hypothesis, Napoli et al. found higher frequencies of deletions and small base transitions in the mitochondrial DNA obtained from ASD children $[119,125]$. Signs of deficient mitochondrial functions in ASD subjects are also apparent in post-mortem brain samples. For example, Tang et al. revealed altered levels of 
proteins involved in the mitochondrial respiratory chain, decreased activity of the respiratory chain, decreased antioxidant levels, as well as more oxidative DNA damage in post-mortem brains of patients affected with ASD [120,126].

\subsection{Dysregulated DNA Repair and DNA Damage}

Insufficiency in DNA repair is an alternative (but not mutually exclusive) mechanism that can precipitate DNA damage in general, and in neurodevelopmental disorders such as schizophrenia and autism in particular. Indeed, several studies have linked polymorphisms in DNA repair genes to the development of schizophrenia and ASD. Intriguingly, genetic polymorphisms in the core BER-protein XRCC1 itself, or in XRCC1 interacting proteins such as Ogg1, have been repeatedly implicated in schizophrenia [121-123,127] and ASD [114,124,128]. The mRNA levels of the DNA glycosylase MBD4 and Ape1 were also reported to be upregulated in the brains of patients with schizophrenia and related disorders $[42,43,51,125]$, adding further evidence for the hypothesis of altered DNA repair in psychotic disorders.

In an effort to assess the cellular capacity for DNA repair in schizophrenia patients, several attempts have been made to measure DNA damage under basal conditions and in response to cellular stressors. Quantification of DNA repair through measurements of unscheduled DNA synthesis in response to methyl methanesulfonate (MMS), methylnitronitrosoguanine (MNNG) and UV radiation [126,129], or through the Comet assay after $\mathrm{H}_{2} \mathrm{O}_{2}$ treatment or $\gamma$-irradiation [127,130], failed to detect any significant differences between cells obtained from patients with schizophrenia and controls. Young et al. reported similar results, yet they found higher levels of DNA damage in male compared to female patients $[128,131]$. The latter results emphasize the importance of assessing phenotypes in a gender-specific manner, similarly to what has been proposed for epidemiologic investigations assessing cancer incidence in schizophrenia (e.g., [42,43,51,132]). Flow cytometric analysis of the DNA double-strand break marker $\gamma \mathrm{H} 2 \mathrm{AX}$ in immortalized lymphoblasts from schizophrenia patients revealed a significantly higher baseline levels of $\gamma \mathrm{H} 2 \mathrm{AX}$ in untreated cells, and a reduced $\gamma \mathrm{H} 2 \mathrm{AX}$ response upon irradiation with 5 Gray $[63,64,67,68,129]$. Higher baseline levels of $\gamma \mathrm{H} 2 \mathrm{AX}$ in untreated cells may mirror pre-existing DNA damage as a result of increased oxidative stress and/or replication stress, whereas a failure to mount sufficient $\gamma \mathrm{H} 2 \mathrm{AX}$ responses may point towards an aberration of the DNA damage response involving $\gamma \mathrm{H} 2 \mathrm{AX}$ formation in lymphoblasts from schizophrenic patients. It should be noted, however, that $\gamma \mathrm{H} 2 \mathrm{AX}$ is only a surrogate marker for cellular stress responses but does not index DNA damage per se. Hence, the extent to which these findings may reflect actual differences in DNA repair still awaits verification.

Attempts to explore DNA repair mechanisms in ASD are limited to a few investigations and have thus far provided equivocal results. For example, cytogenetic analyses of chromosome fragile sites initially revealed significant differences in chromosome lesions in ASD patients relative to controls $[130,133]$. In contrast, a comparison between lymphocytes from ASD children, unaffected siblings and community controls showed no signs for genomic instability using the cytokinesis-block micronucleus assay (CBMA) [76,131]. While the latter assay allows detection of gross molecular events like chromosome breakage, loss or rearrangement, it is unable to detect more subtle changes in DNA structure and repair. Therefore, these findings leave the question unanswered as to whether ASD patients may display more subtle damage to DNA or not. Comparing lymphoblasts from ASD children and their siblings, Main et al. further found an increased sensitivity of ASD samples to necrosis caused by oxidative stress. At the same time, the authors revealed no difference in DNA damage using the CBMA assay [132,133], suggesting that ASD patients do not display gross abnormalities in DNA structure and repair.

Taken together, there is accumulating evidence supporting a role of increased oxidative stress and impaired mitochondrial functions in schizophrenia and ASD. However, the available data are inconclusive, so that additional research will be needed to ascertain whether or not DNA repair mechanisms are altered in these disorders. Whilst genetic linkage studies readily support this 
hypothesis, the nature and/or severity of abnormal DNA repair and damage in schizophrenia and ASD await further exploration.

\section{DNA Repair and Damage in Schizophrenia and Autism: A Role beyond Altered Cancer Risk?}

In view of the crucial roles of genomic stability and DNA repair in cancer $[63,64,67,68,133]$, it appears plausible that altered expression of DNA repair genes and/or functional impairments in DNA repair mechanisms may contribute to altered cancer risk in schizophrenia and autism. Exploring this putative relationship clearly warrants future investigation as it may help advance our understanding of why certain types of cancers are more prevalent in patients with schizophrenia or ASD, whereas others seem to be less common in these neurodevelopmental disorders (see Section 2). Another burning question in this context is whether altered DNA repair and/or DNA damage may play an aetiopathological role beyond cancer risk. Or in other words: is there a pathological connection between altered DNA repair pathways and abnormal brain development relevant to the neurodevelopmental origins of schizophrenia and ASD?

Experimental work in animal models has recently begun examining this question. Bjørge et al. used a mouse model, in which the expression of the two DNA glycosylases Ogg1 and MUTYH was genetically ablated $[133,134]$. As discussed above, Ogg1 and MUTYH are both involved in the removal of the oxidative DNA lesion 8-oxo-G, so that their ablation are expected to increase DNA damage in dividing cells [76]. The authors found that loss of both these glycosylases induced a synergistic effect on anxiety-like behaviour [133,135-137]. Transcriptomic analysis of the hippocampi of these mice revealed a possible role of the two glycosylases in hippocampal gene expression, which related primarily to mal-adaptive behaviour. However, Ogg1 and MUTYH double-knockout animals did not display overt changes in 8-oxo-G levels in any of the brain tissue analysed [133,138], making it difficult to attribute the observed behavioural and transcriptional changes to DNA damage. An alternative (and more likely) explanation for the behavioural induced by Ogg1 and MUTYH ablation is that the genetic manipulation interfered with transcription independently of 8-oxo-G processing in the brain. Furthermore, the lack of 8-oxo-G accumulation following Ogg1 and MUTYH could be the result of redundancies in pathways catalysing its removal, an effect that may be particularly pronounced in the CNS due to the postmitotic nature of brain cells.

Selected deficits in learning and memory have also been observed in mice deficient of other DNA glycosylases, including Neil1 and Neil3 [134,139] and reviewed in [76,140]. Even though the relative contribution of altered DNA repair and DNA damage remains elusive in these models, these findings indicate that the loss of these DNA glycosylases exerts a long-lasting impact on cognitive functions. Based on these promising findings, extending the phenotypes of Neil1 and Neil3 ablation to other behavioural and cognitive functions relevant to schizophrenia and ASD, including social interaction, central information processing and filtering, sustained and selective attention, and working memory, seems highly warranted [135-137,141].

Long-lasting neural defects have also been identified in mice with genetic XRCC1 deficiency [138]. A reduction of XRCC1 levels leads to a decrease in the overall BER capacity of a cell, primarily because Pol $\beta$ and Lig III are unstable in the absence of XRCC1 as scaffolding protein $[139,142,143]$. This leads to the accumulation of endogenous SSBs in primary cells, even in the absence of exogenously administered DNA damaging agents, as endogenously arising lesions are not repaired properly and in time [140]. The complete knockout of XRCC1 is embryonically lethal, possibly because of a failure to repair DNA breaks arising during embryonic development [141]. To circumvent this problem, Lee et al. (2009) developed an XRCC1-loxP mouse that allows a conditional ablation of XRCC1 in specific tissues when crossed with the appropriate Cre-driver mouse expressing the cre-recombinase in the tissue of interest [138]. Using this approach, they showed that Nes-Cre driven ablation of XRCC1 in the CNS leads to impaired development of the cerebellum and hippocampus, two brain regions strongly implicated in neurodevelopmental disorders such as schizophrenia and ASD $[142,143]$. These abnormalities seemed to arise from a persistent accumulation of single-strand 
strand breaks in mature neuronal populations and markedly affect $\gamma$-aminobutyric acid (GABA) interneurons [138]. The latter effects are of particular interest because cellular abnormalities in GABAergic circuitries are hallmark neuropathological features of neurodevelopmental brain disorders such as schizophrenia and autism $[144,145]$. GABAergic interneurons critically regulate neuronal oscillatory activity [146], which in turn is believed to serve various complex functions, including perception, cognition, and memory [147]. Hence, impairments in GABAergic functions resulting from genetic XRCC1 deficiency may cause a spectrum of behavioural and cognitive deficits that are reminiscent of functional deteriorations in developmental neuropsychiatric disorders. Whether DNA damage is directly involved in the aetiopathology of schizophrenia and ASD, however, still awaits direct examination.

\section{Conclusions and Perspectives}

To summarize, direct experimental evidence for the hypothesis that DNA damage and/or genetic disruptions of DNA repair genes can causally contribute to the onset of schizophrenia and ASD is slowly growing. Nevertheless, whether DNA damage and DNA repair is causally connected to ASD and schizophrenia remains controversial. Indeed, the current status of research is still far from rendering even a rudimentary picture of all the possible mechanisms involved, or understanding how, and in which phase, which particular source of DNA damage leads to alterations relevant to schizophrenia and autism. Here, it will be highly interesting and important also to dissect the contribution of the DNA damaging insult occurring during prenatal development versus damage incurred throughout adolescence or adulthood. Furthermore, it remains completely unclear how DNA damage mechanistically drives cellular changes that drive the observed phenotype in these disorders. Another salient feature in respect to patient-based epidemiological studies is the observation of gender-specific differences pertaining to certain traits, as seen for cancer incidence reports. Future research-not only in this field, but also in other biomedical research-will probably have to address these gender-specific variations more thoroughly when assessing phenotypes, both in epidemiological as well as in basic research settings. Detailed analysis of all these aspects warrants future investigations to broaden our understanding of the underlying mechanisms, and has the potential to spark development of novel therapeutic approaches to cure, or at least alleviate the severity, of neurodevelopmental diseases.

Author Contributions: Enni Markkanen wrote the first draft, Urs Meyer elaborated on schizophrenia and ASD, and Grigory L. Dianov provided inputs and feedback. All three authors contributed to the final version.

Conflicts of Interest: The authors declare no conflict of interest.

\section{References}

1. Fombonne, E. Epidemiology of pervasive developmental disorders. Pediatr. Res. 2009, 65, 591-598. [CrossRef] [PubMed]

2. Tandon, R.; Nasrallah, H.A.; Keshavan, M.S. Schizophrenia, "just the facts" 4. Clinical features and conceptualization. Schizophr. Res. 2009, 110,1-23. [CrossRef] [PubMed]

3. Rapin, I.; Tuchman, R.F. Autism: Definition, neurobiology, screening, diagnosis. Pediatr. Clin. N. Am. 2008, 55, 1129-1146. [CrossRef] [PubMed]

4. Whiteford, H.A.; Degenhardt, L.; Rehm, J.; Baxter, A.J.; Ferrari, A.J.; Erskine, H.E.; Charlson, F.J.; Norman, R.E.; Flaxman, A.D.; Johns, N.; et al. Global burden of disease attributable to mental and substance use disorders: Findings from the Global Burden of Disease Study 2010. Lancet 2013, 382, 1575-1586. [CrossRef]

5. Silberberg, D.; Anand, N.P.; Michels, K.; Kalaria, R.N. Brain and other nervous system disorders across the lifespan-Global challenges and opportunities. Nature 2015, 527, S151-S154. [CrossRef] [PubMed]

6. Mehling, M.H.; Tassé, M.J. Severity of autism spectrum disorders: Current conceptualization, and transition to DSM-5. J. Autism. Dev. Disord. 2016, 46, 2000-2016. [CrossRef] [PubMed] 
7. Tarabeux, J.; Kebir, O.; Gauthier, J.; Hamdan, F.F.; Xiong, L.; Piton, A.; Spiegelman, D.; Henrion, É.; Millet, B.; Fathalli, F; et al. Rare mutations in N-methyl-D-aspartate glutamate receptors in autism spectrum disorders and schizophrenia. Trans. Psychiatry 2011, 1, e55. [CrossRef] [PubMed]

8. Gao, R.; Penzes, P. Common mechanisms of excitatory and inhibitory imbalance in schizophrenia and autism spectrum disorders. Curr. Mol. Med. 2015, 15, 146-167. [CrossRef] [PubMed]

9. Kruhøffer, M.; Jensen, J.L.; Laiho, P.; Dyrskjøt, L.; Salovaara, R.; Arango, D.; Birkenkamp-Demtroder, K.; Sørensen, F.B.; Christensen, L.L.; Buhl, L.; et al. Gene expression signatures for colorectal cancer microsatellite status and HNPCC. Br. J. Cancer 2005, 92, 2240-2248. [CrossRef] [PubMed]

10. Uzunova, G.; Pallanti, S.; Hollander, E. Excitatory/inhibitory imbalance in autism spectrum disorders: Implications for interventions and therapeutics. World J. Biol. Psychiatry 2015, 17, 1-13. [CrossRef] [PubMed]

11. Weinberger, D.R. Implications of normal brain development for the pathogenesis of schizophrenia. Arch. Gen. Psychiatry 1987, 44, 660-669. [CrossRef] [PubMed]

12. Rapoport, J.L.; Giedd, J.N.; Gogtay, N. Neurodevelopmental model of schizophrenia: Update 2012. Mol. Psychiatry 2012, 17, 1228-1238. [CrossRef] [PubMed]

13. Cheung, C.; Yu, K.; Fung, G.; Leung, M.; Wong, C.; Li, Q.; Sham, P.; Chua, S.; McAlonan, G. Autistic disorders and schizophrenia: Related or remote? An anatomical likelihood estimation. PLoS ONE 2010, 5, e12233. [CrossRef] [PubMed]

14. Ecker, C.; Bookheimer, S.Y.; Murphy, D.G.M. Neuroimaging in autism spectrum disorder: Brain structure and function across the lifespan. Lancet Neurol. 2015, 14, 1121-1134. [CrossRef]

15. Selemon, L.D.; Zecevic, N. Schizophrenia: A tale of two critical periods for prefrontal cortical development. Trans. Psychiatry 2015, 5, e623. [CrossRef] [PubMed]

16. Ziats, M.N.; Edmonson, C.; Rennert, O.M. The autistic brain in the context of normal neurodevelopment. Front. Neuroanat. 2015, 9, 115. [CrossRef] [PubMed]

17. Brown, A.S. The environment and susceptibility to schizophrenia. Prog. Neurobiol. 2011, 93, 23-58. [CrossRef] [PubMed]

18. Pinkham, A.E.; Hopfinger, J.B.; Pelphrey, K.A.; Piven, J.; Penn, D.L. Neural bases for impaired social cognition in schizophrenia and autism spectrum disorders. Schizophr. Res. 2008, 99, 164-175. [CrossRef] [PubMed]

19. Giusti-Rodríguez, P.; Sullivan, P.F. The genomics of schizophrenia: Update and implications. J. Clin. Investig. 2013, 123, 4557-4563. [CrossRef] [PubMed]

20. Farrell, M.S.; Werge, T.; Sklar, P.; Owen, M.J.; Ophoff, R.A.; O’Donovan, M.C.; Corvin, A.; Cichon, S.; Sullivan, P.F. Evaluating historical candidate genes for schizophrenia. Mol. Psychiatry 2015, 20, 555-562. [CrossRef] [PubMed]

21. Kim, Y.S.; Leventhal, B.L. Genetic epidemiology and insights into interactive genetic and environmental effects in autism spectrum disorders. Biol. Psychiatry 2015, 77, 66-74. [CrossRef] [PubMed]

22. Mandy, W.; Lai, M.-C. Annual Research Review: The role of the environment in the developmental psychopathology of autism spectrum condition. J. Child Psychol. Psychiatry 2016, 57, 271-292. [CrossRef] [PubMed]

23. Van Os, J.; Rutten, B.P.; Poulton, R. Gene-environment interactions in schizophrenia: Review of epidemiological findings and future directions. Schizophr. Bull. 2008, 34, 1066-1082. [CrossRef] [PubMed]

24. Lee, S.H.; Ripke, S.; Neale, B.M.; Faraone, S.V.; Purcell, S.M.; Perlis, R.H.; Mowry, B.J.; Thapar, A.; Goddard, M.E.; Witte, J.S.; et al. International Inflammatory Bowel Disease Genetics Consortium (IIBDGC). Genetic relationship between five psychiatric disorders estimated from genome-wide SNPs. Nat. Genet. 2013, 45, 984-994. [CrossRef] [PubMed]

25. Sullivan, P.F.; Kendler, K.S.; Neale, M.C. Schizophrenia as a complex trait: Evidence from a meta-analysis of twin studies. Arch. Gen. Psychiatry 2003, 60, 1187-1192. [CrossRef] [PubMed]

26. Uher, R. Gene-environment interactions in common mental disorders: An update and strategy for a genome-wide search. Soc. Psychiatry Psychiatr. Epidemiol. 2014, 49, 3-14. [CrossRef] [PubMed]

27. Van Os, J.; Rutten, B.P.; Myin-Germeys, I.; Delespaul, P.; Viechtbauer, W.; van Zelst, C.; Bruggeman, R.; Reininghaus, U.; Morgan, C.; Murray, R.M.; et al. Identifying gene-environment interactions in schizophrenia: Contemporary challenges for integrated, large-scale investigations. Schizophr. Bull. 2014, 40, 729-736. [PubMed]

28. Insel, T.R. Rethinking schizophrenia. Nature 2010, 468, 187-193. [CrossRef] [PubMed] 
29. Tandon, R.; Nasrallah, H.A.; Keshavan, M.S. Schizophrenia, “just the facts" 5. Treatment and prevention. Past, present, and future. Schizophr. Res. 2010, 122, 1-23. [CrossRef] [PubMed]

30. Ruhela, R.K.; Prakash, A.; Medhi, B. An urgent need for experimental animal model of autism in drug development. Ann. Neurosci. 2015, 22, 44-49. [CrossRef] [PubMed]

31. Bauman, M.L. Medical comorbidities in autism: Challenges to diagnosis and treatment. Neurotherapeutics 2010, 7, 320-327. [CrossRef] [PubMed]

32. Kirkpatrick, B. Schizophrenia as a systemic disease. Schizophr. Bull. 2009, 35, 381-382. [CrossRef] [PubMed]

33. Tabarés-Seisdedos, R.; Dumont, N.; Baudot, A.; Valderas, J.M.; Climent, J.; Valencia, A.; Crespo-Facorro, B.; Vieta, E.; Gómez-Beneyto, M.; Martinez, S.; et al. No paradox, no progress: Inverse cancer comorbidity in people with other complex diseases. Lancet Oncol. 2011, 12, 604-608. [CrossRef]

34. Gejman, P.V.; Sanders, A.R.; Duan, J. The role of genetics in the etiology of schizophrenia. Psychiatr. Clin. N. Am. 2010, 33, 35-66. [CrossRef] [PubMed]

35. Torrey, E.F. Are we overestimating the genetic contribution to schizophrenia? Schizophr. Bull. 1992, 18, 159-170. [CrossRef] [PubMed]

36. Schwartz, S.; Susser, E. Commentary: What can epidemiology accomplish? Int. J. Epidemiol. 2006, 35, 587-590, discussion 593-596. [CrossRef] [PubMed]

37. Patterson, P.H. Neuroscience. Maternal effects on schizophrenia risk. Science 2007, 318, 576-577. [CrossRef] [PubMed]

38. Van Vugt, J.M.G.; Shulman, L.P. Prenatal Medicine; Taylor \& Francis Group: New York, NY, USA, 2006.

39. Hsiao, E.Y.; Patterson, P.H. Placental regulation of maternal-fetal interactions and brain development. Dev. Neurobiol. 2012, 72, 1317-1326. [CrossRef] [PubMed]

40. Hodgson, R.; Wildgust, H.J.; Bushe, C.J. Cancer and schizophrenia: Is there a paradox? J. Psychopharmacol. (Oxf.) 2010, 24, 51-60. [CrossRef] [PubMed]

41. Bushe, C.J.; Bradley, A.J.; Wildgust, H.J.; Hodgson, R.E. Schizophrenia and breast cancer incidence: A systematic review of clinical studies. Schizophr. Res. 2009, 114, 6-16. [CrossRef] [PubMed]

42. Mortensen, P.B. The incidence of cancer in schizophrenic patients. J. Epidemiol. Community Health 1989, 43, 43-47. [CrossRef] [PubMed]

43. Mortensen, P.B. The occurrence of cancer in first admitted schizophrenic patients. Schizophr. Res. 1994, 12, 185-194. [CrossRef]

44. Cohen, M.; Dembling, B.; Schorling, J. The association between schizophrenia and cancer: A population-based mortality study. Schizophr. Res. 2002, 57, 139-146. [CrossRef]

45. Barak, Y.; Achiron, A.; Mandel, M.; Mirecki, I.; Aizenberg, D. Reduced cancer incidence among patients with schizophrenia. Cancer 2005, 104, 2817-2821. [CrossRef] [PubMed]

46. Chou, F.H.-C.; Tsai, K.-Y.; Su, C.-Y.; Lee, C.-C. The incidence and relative risk factors for developing cancer among patients with schizophrenia: A nine-year follow-up study. Schizophr. Res. 2011, 129, 97-103. [CrossRef] [PubMed]

47. Ji, J.; Sundquist, K.; Ning, Y.; Kendler, K.S.; Sundquist, J.; Chen, X. Incidence of cancer in patients with schizophrenia and their first-degree relatives: A population-based study in Sweden. Schizophr. Bull. 2013, 39, 527-536. [CrossRef]

48. Lichtermann, D.; Ekelund, J.; Pukkala, E.; Tanskanen, A.; Lönnqvist, J. Incidence of cancer among persons with schizophrenia and their relatives. Arch. Gen. Psychiatry 2001, 58, 573-578. [CrossRef] [PubMed]

49. Ajdacic-Gross, V.; Tschopp, A.; Bopp, M.; Gutzwiller, F.; Rössler, W. Cancer comortality patterns in schizophrenia and psychotic disorders: A new methodological approach for unique databases. Int. J. Methods Psychiatr. Res. 2014, 23, 19-24. [CrossRef] [PubMed]

50. Catalá-López, F.; Suárez-Pinilla, M.; Suárez-Pinilla, P.; Valderas, J.M.; Gómez-Beneyto, M.; Martinez, S.; Balanzá-Martínez, V.; Climent, J.; Valencia, A.; McGrath, J.; et al. Inverse and direct cancer comorbidity in people with central nervous system disorders: A meta-analysis of cancer incidence in 577,013 participants of 50 observational studies. Psychother. Psychosom. 2014, 83, 89-105. [CrossRef] [PubMed]

51. Lin, G.-M.; Chen, Y.-J.; Kuo, D.-J.; Jaiteh, L.E.S.; Wu, Y.-C.; Lo, T.-S.; Li, Y.-H. Cancer incidence in patients with schizophrenia or bipolar disorder: A nationwide population-based study in Taiwan, 1997-2009. Schizophr. Bull. 2013, 39, 407-416. [CrossRef] [PubMed]

52. Catts, V.S.; Catts, S.V.; O'Toole, B.I.; Frost, A.D.J. Cancer incidence in patients with schizophrenia and their first-degree relatives-A meta-analysis. Acta Psychiatr. Scand. 2008, 117, 323-336. [CrossRef] [PubMed] 
53. Leucht, S.; Burkard, T.; Henderson, J.; Maj, M.; Sartorius, N. Physical illness and schizophrenia: A review of the literature. Acta Psychiatr. Scand. 2007, 116, 317-333.

54. Howard, L.M.; Barley, E.A.; Davies, E.; Rigg, A.; Lempp, H.; Rose, D.; Taylor, D.; Thornicroft, G. Cancer diagnosis in people with severe mental illness: Practical and ethical issues. Lancet Oncol. 2010, 11, 797-804. [CrossRef]

55. Fond, G.; Macgregor, A.; Attal, J.; Larue, A.; Brittner, M.; Ducasse, D.; Capdevielle, D. Antipsychotic drugs: Pro-cancer or anti-cancer? A systematic review. Med. Hypotheses 2012, 79, 38-42. [CrossRef] [PubMed]

56. Irwin, K.E.; Henderson, D.C.; Knight, H.P.; Pirl, W.F. Cancer care for individuals with schizophrenia. Cancer 2014, 120, 323-334. [CrossRef] [PubMed]

57. Crespi, B. Autism and cancer risk. Autism. Res. 2011, 4, 302-310. [CrossRef] [PubMed]

58. Kao, H.-T.; Buka, S.L.; Kelsey, K.T.; Gruber, D.F.; Porton, B. The correlation between rates of cancer and autism: An exploratory ecological investigation. PLoS ONE 2010, 5, e9372. [CrossRef] [PubMed]

59. Crawley, J.N.; Heyer, W.-D.; LaSalle, J.M. Autism and cancer share risk genes, pathways, and drug targets. Trends Genet. 2016, 32, 139-146. [CrossRef] [PubMed]

60. De Rubeis, S.; Buxbaum, J.D. Genetics and genomics of autism spectrum disorder: Embracing complexity. Hum. Mol. Genet. 2015, 24, R24-R31. [CrossRef] [PubMed]

61. Liu, X.; Takumi, T. Genomic and genetic aspects of autism spectrum disorder. Biochem. Biophys. Res. Commun. 2014, 452, 244-253. [CrossRef] [PubMed]

62. Vorstman, J.A.S.; Staal, W.G.; van Daalen, E.; van Engeland, H.; Hochstenbach, P.F.R.; Franke, L. Identification of novel autism candidate regions through analysis of reported cytogenetic abnormalities associated with autism. Mol. Psychiatry 2006, 11, 18-28. [CrossRef] [PubMed]

63. Hanahan, D.; Weinberg, R.A. Hallmarks of cancer: The next generation. Cell 2011, 144, 646-674. [CrossRef] [PubMed]

64. Stratton, M.R.; Campbell, P.J.; Futreal, P.A. The cancer genome. Nature 2009, 458, 719-724. [CrossRef] [PubMed]

65. Van Loon, B.; Markkanen, E.; Hübscher, U. Oxygen as a friend and enemy: How to combat the mutational potential of 8-oxo-guanine. DNA Repair 2010, 9, 604-616. [CrossRef] [PubMed]

66. Jackson, S.P.; Bartek, J. The DNA-damage response in human biology and disease. Nature 2009, 461, 1071-1078. [CrossRef] [PubMed]

67. Alexandrov, L.B.; Nik-Zainal, S.; Wedge, D.C.; Aparicio, S.A.J.R.; Behjati, S.; Biankin, A.V.; Bignell, G.R.; Bolli, N.; Borg, A.; Børresen-Dale, A.-L.; et al. Signatures of mutational processes in human cancer. Nature 2013, 500, 415-421. [CrossRef] [PubMed]

68. Bartkova, J.; Horejsí, Z.; Koed, K.; Krämer, A.; Tort, F.; Zieger, K.; Guldberg, P.; Sehested, M.; Nesland, J.M.; Lukas, C.; et al. DNA damage response as a candidate anti-cancer barrier in early human tumorigenesis. Nature 2005, 434, 864-870. [CrossRef] [PubMed]

69. Beckman, K.B.; Ames, B.N. Oxidative decay of DNA. J. Biol. Chem. 1997, 272, 19633-19636. [CrossRef] [PubMed]

70. Lindahl, T. Instability and decay of the primary structure of DNA. Nature 1993, 362, 709-715. [CrossRef] [PubMed]

71. Dianov, G.L.; Hübscher, U. Mammalian base excision repair: The forgotten archangel. Nucleic Acids Res. 2013, 2013, gkt076. [CrossRef] [PubMed]

72. Lombard, D.B.; Chua, K.F.; Mostoslavsky, R.; Franco, S.; Gostissa, M.; Alt, F.W. DNA repair, genome stability, and aging. Cell 2005, 120, 497-512. [CrossRef] [PubMed]

73. Caldecott, K.W. Single-strand break repair and genetic disease. Nat. Rev. Genet. 2008, 9, 619-631. [PubMed]

74. Hegde, M.L.; Mantha, A.K.; Hazra, T.K.; Bhakat, K.K.; Mitra, S.; Szczesny, B. Oxidative genome damage and its repair: Implications in aging and neurodegenerative diseases. Mech. Ageing Dev. 2012, 133, 157-168. [CrossRef] [PubMed]

75. Canugovi, C.; Misiak, M.; Ferrarelli, L.K.; Croteau, D.L.; Bohr, V.A. The role of DNA repair in brain related disease pathology. DNA Repair 2013, 12, 578-587. [CrossRef] [PubMed]

76. Bosshard, M.; Markkanen, E.; van Loon, B. Base excision repair in physiology and pathology of the central nervous system. Int. J. Mol. Sci. 2012, 13, 16172-16222. [CrossRef] [PubMed]

77. Jacobs, A.L.; Schär, P. DNA glycosylases: In DNA repair and beyond. Chromosoma 2012, 121, 1-20. [CrossRef] [PubMed] 
78. Wallace, S.S.; Murphy, D.L.; Sweasy, J.B. Base excision repair and cancer. Cancer Lett. 2012, 327, 73-89. [CrossRef] [PubMed]

79. Markkanen, E.; Dorn, J.; Hübscher, U. MUTYH DNA glycosylase: The rationale for removing undamaged bases from the DNA. Front. Genet. 2013, 4, 18. [CrossRef] [PubMed]

80. Markkanen, E.; van Loon, B.; Ferrari, E.; Parsons, J.L.; Dianov, G.L.; Hübscher, U. Regulation of oxidative DNA damage repair by DNA polymerase $\lambda$ and MutYH by cross-talk of phosphorylation and ubiquitination. Proc. Natl. Acad. Sci. USA 2012, 109, 437-442. [CrossRef] [PubMed]

81. Markkanen, E.; Hübscher, U.; van Loon, B. Regulation of oxidative DNA damage repair: The adenine: 8-oxo-guanine problem. Cell Cycle 2012, 11, 1070-1075. [CrossRef] [PubMed]

82. Van Loon, B.; Hübscher, U. An 8-oxo-guanine repair pathway coordinated by MUTYH glycosylase and DNA polymerase $\lambda$. Proc. Natl. Acad. Sci. USA 2009, 106, 18201-18206. [CrossRef] [PubMed]

83. Lavin, M.F. Ataxia-telangiectasia: From a rare disorder to a paradigm for cell signalling and cancer. Nat. Rev. Mol. Cell Biol. 2008, 9, 759-769. [CrossRef] [PubMed]

84. Patterson, D. Molecular genetic analysis of down syndrome. Hum. Genet. 2009, 126, 195-214. [CrossRef] [PubMed]

85. Rabin, K.R.; Whitlock, J.A. Malignancy in children with trisomy 21. Oncologist 2009, 14, 164-173. [CrossRef] [PubMed]

86. Kern, J.K.; Jones, A.M. Evidence of toxicity, oxidative stress, and neuronal insult in autism. J. Toxicol. Environ. Health Part B 2006, 9, 485-499. [CrossRef] [PubMed]

87. Chauhan, A.; Chauhan, V. Oxidative stress in autism. Pathophysiology 2006, 13, 171-181. [CrossRef] [PubMed]

88. Chauhan, A.; Chauhan, V.; Brown, W.T.; Cohen, I. Oxidative stress in autism: Increased lipid peroxidation and reduced serum levels of ceruloplasmin and transferrin-The antioxidant proteins. Life Sci. 2004, 75, 2539-2549. [CrossRef] [PubMed]

89. Clay, H.B.; Sillivan, S.; Konradi, C. Mitochondrial dysfunction and pathology in bipolar disorder and schizophrenia. Int. J. Dev. Neurosci. 2011, 29, 311-324. [CrossRef] [PubMed]

90. Pandya, C.D.; Howell, K.R.; Pillai, A. Antioxidants as potential therapeutics for neuropsychiatric disorders. Prog. Neuropsychopharmacol. Biol. Psychiatry 2013, 46, 214-223. [CrossRef] [PubMed]

91. Larsson, N.-G. Somatic mitochondrial DNA mutations in mammalian aging. Annu. Rev. Biochem. 2010, 79, 683-706. [CrossRef] [PubMed]

92. Korotkova, E.I.; Misini, B.; Dorozhko, E.V.; Bukkel, M.V.; Plotnikov, E.V.; Linert, W. Study of OH radicals in human serum blood of healthy individuals and those with pathological schizophrenia. Int. J. Mol. Sci. 2011, 12, 401-410. [CrossRef] [PubMed]

93. Lagouge, M.; Larsson, N.-G. The role of mitochondrial DNA mutations and free radicals in disease and ageing. J. Int. Med. 2013, 273, 529-543. [CrossRef] [PubMed]

94. Herken, H.; Uz, E.; Ozyurt, H.; Söğüt, S.; Virit, O.; Akyol, O. Evidence that the activities of erythrocyte free radical scavenging enzymes and the products of lipid peroxidation are increased in different forms of schizophrenia. Mol. Psychiatry 2001, 6, 66-73. [CrossRef] [PubMed]

95. Pinto, M.; Moraes, C.T. Mechanisms linking mtDNA damage and aging. Free Radic. Biol. Med. 2015, 85, 250-258. [CrossRef] [PubMed]

96. Dietrich-Muszalska, A.; Olas, B. Modifications of blood platelet proteins of patients with schizophrenia. Platelets 2009, 20, 90-96. [CrossRef] [PubMed]

97. Sirota, P.; Gavrieli, R.; Wolach, B. Overproduction of neutrophil radical oxygen species correlates with negative symptoms in schizophrenic patients: Parallel studies on neutrophil chemotaxis, superoxide production and bactericidal activity. Psychiatry Res. 2003, 121, 123-132. [CrossRef]

98. Grima, G.; Benz, B.; Parpura, V.; Cuénod, M.; Do, K.Q. Dopamine-induced oxidative stress in neurons with glutathione deficit: Implication for schizophrenia. Schizophr. Res. 2003, 62, 213-224. [CrossRef]

99. Do, K.Q.; Trabesinger, A.H.; Kirsten-Krüger, M.; Lauer, C.J.; Dydak, U.; Hell, D.; Holsboer, F.; Boesiger, P.; Cuénod, M. Schizophrenia: Glutathione deficit in cerebrospinal fluid and prefrontal cortex in vivo. Eur. J. Neurosci. 2000, 12, 3721-3728. [CrossRef] [PubMed]

100. Yao, J.K.; Leonard, S.; Reddy, R.D. Increased nitric oxide radicals in postmortem brain from patients with schizophrenia. Schizophr. Bull. 2004, 30, 923-934. [CrossRef] [PubMed] 
101. Kim, H.K.; Andreazza, A.C.; Yeung, P.Y.; Isaacs-Trepanier, C.; Young, L.T. Oxidation and nitration in dopaminergic areas of the prefrontal cortex from patients with bipolar disorder and schizophrenia. J. Psychiatry Neurosci. 2014, 39, 276-285. [CrossRef] [PubMed]

102. Jorgensen, A.; Broedbaek, K.; Fink-Jensen, A.; Knorr, U.; Greisen Soendergaard, M.; Henriksen, T.; Weimann, A.; Jepsen, P.; Lykkesfeldt, J.; Poulsen, H.E.; et al. Increased systemic oxidatively generated DNA and RNA damage in schizophrenia. Psychiatry Res. 2013, 209, 417-423. [CrossRef] [PubMed]

103. Muraleedharan, A.; Menon, V.; Rajkumar, R.P.; Chand, P. Assessment of DNA damage and repair efficiency in drug naïve schizophrenia using comet assay. J. Psychiatr. Res. 2015, 68, 47-53. [CrossRef] [PubMed]

104. Mahadik, S.P.; Evans, D.; Lal, H. Oxidative stress and role of antioxidant and $\omega-3$ essential fatty acid supplementation in schizophrenia. Prog. Neuropsychopharmacol. Biol. Psychiatry 2001, 25, 463-493. [CrossRef]

105. Sertan Copoglu, U.; Virit, O.; Hanifi Kokacya, M.; Orkmez, M.; Bulbul, F.; Binnur Erbagci, A.; Semiz, M.; Alpak, G.; Unal, A.; Ari, M.; et al. Increased oxidative stress and oxidative DNA damage in non-remission schizophrenia patients. Psychiatry Res. 2015, 229, 200-205. [CrossRef] [PubMed]

106. Emiliani, F.E.; Sedlak, T.W.; Sawa, A. Oxidative stress and schizophrenia. Curr. Opin. Psychiatry 2014, 27, 185-190. [CrossRef] [PubMed]

107. Nishioka, N.; Arnold, S.E. Evidence for oxidative DNA damage in the hippocampus of elderly patients with chronic schizophrenia. Am. J. Geriatr. Psychiatry 2004, 12, 167-175. [CrossRef] [PubMed]

108. Mamdani, F.; Rollins, B.; Morgan, L.; Sequeira, P.A.; Vawter, M.P. The somatic common deletion in mitochondrial DNA is decreased in schizophrenia. Schizophr. Res. 2014, 159, 370-375. [CrossRef] [PubMed]

109. Steullet, P.; Cabungcal, J.-H.; Kulak, A.; Kraftsik, R.; Chen, Y.; Dalton, T.P.; Cuénod, M.; Do, K.Q. Redox dysregulation affects the ventral but not dorsal hippocampus: Impairment of parvalbumin neurons, gamma oscillations, and related behaviors. J. Neurosci. 2010, 30, 2547-2558. [CrossRef] [PubMed]

110. Cabungcal, J.-H.; Steullet, P.; Kraftsik, R.; Cuénod, M.; Do, K.Q. Early-life insults impair parvalbumin interneurons via oxidative stress: Reversal by $N$-acetylcysteine. Biol. Psychiatry 2013, 73, 574-582. [CrossRef] [PubMed]

111. Cabungcal, J.-H.; Counotte, D.S.; Lewis, E.M.; Tejeda, H.A.; Piantadosi, P.; Pollock, C.; Calhoon, G.G.; Sullivan, E.M.; Presgraves, E.; Kil, J.; et al. Juvenile antioxidant treatment prevents adult deficits in a developmental model of schizophrenia. Neuron 2014, 83, 1073-1084. [CrossRef] [PubMed]

112. Cabungcal, J.-H.; Steullet, P.; Morishita, H.; Kraftsik, R.; Cuénod, M.; Hensch, T.K.; Do, K.Q. Perineuronal nets protect fast-spiking interneurons against oxidative stress. Proc. Natl. Acad Sci. USA 2013, 110, 9130-9135. [CrossRef] [PubMed]

113. Trifunovic, A. Mitochondrial DNA and ageing. Biochim. Biophys. Acta 2006, 1757, 611-617. [CrossRef] [PubMed]

114. Shpyleva, S.; Ivanovsky, S.; de Conti, A.; Melnyk, S.; Tryndyak, V.; Beland, F.A.; James, S.J.; Pogribny, I.P. Cerebellar oxidative DNA damage and altered DNA methylation in the BTBR T+tf/J mouse model of autism and similarities with human post mortem cerebellum. PLoS ONE 2014, 9, e113712. [CrossRef] [PubMed]

115. Sajdel-Sulkowska, E.M.; Xu, M.; Koibuchi, N. Increase in cerebellar neurotrophin-3 and oxidative stress markers in autism. Cerebellum 2009, 8, 366-372. [CrossRef] [PubMed]

116. Chauhan, A.; Audhya, T.; Chauhan, V. Brain region-specific glutathione redox imbalance in autism. Neurochem. Res. 2012, 37, 1681-1689. [CrossRef] [PubMed]

117. Rose, S.; Melnyk, S.; Pavliv, O.; Bai, S.; Nick, T.G.; Frye, R.E.; James, S.J. Evidence of oxidative damage and inflammation associated with low glutathione redox status in the autism brain. Trans. Psychiatry 2012, 2, e134. [CrossRef] [PubMed]

118. Melnyk, S.; Fuchs, G.J.; Schulz, E.; Lopez, M.; Kahler, S.G.; Fussell, J.J.; Bellando, J.; Pavliv, O.; Rose, S.; Seidel, L.; et al. Metabolic imbalance associated with methylation dysregulation and oxidative damage in children with autism. J. Autism. Dev. Disord. 2012, 42, 367-377. [CrossRef] [PubMed]

119. Napoli, E.; Wong, S.; Giulivi, C. Evidence of reactive oxygen species-mediated damage to mitochondrial DNA in children with typical autism. Mol. Autism. 2013, 4, 2. [CrossRef] [PubMed]

120. Tang, G.; Gutierrez Rios, P.; Kuo, S.-H.; Akman, H.O.; Rosoklija, G.; Tanji, K.; Dwork, A.; Schon, E.A.; Dimauro, S.; Goldman, J.; et al. Mitochondrial abnormalities in temporal lobe of autistic brain. Neurobiol. Dis. 2013, 54, 349-361. [CrossRef] [PubMed]

121. Saadat, M.; Pakyari, N.; Farrashbandi, H. Genetic polymorphism in the DNA repair gene XRCC1 and susceptibility to schizophrenia. Psychiatry Res. 2008, 157, 241-245. [CrossRef] [PubMed] 
122. Derakhshandeh, S.; Saadat, I.; Farrashbandi, H.; Saadat, M. Association between genetic polymorphism of XRCC1 Arg194Trp and risk of schizophrenia. Psychiatry Res. 2009, 169, 186. [CrossRef] [PubMed]

123. Odemis, S.; Tuzun, E.; Gulec, H.; Semiz, U.B.; Dasdemir, S.; Kucuk, M.; Yalcınkaya, N.; Bireller, E.S.; Cakmakoglu, B.; Küçükali, C.I. Association between polymorphisms of DNA repair genes and risk of schizophrenia. Genet. Test. Mol. Biomark. 2015, 20, 11-17. [CrossRef] [PubMed]

124. Xu, H.; Rosales-Reynoso, M.A.; Barros-Núñez, P.; Peprah, E. DNA repair/replication transcripts are down regulated in patients with Fragile X Syndrome. BMC Res. Notes 2013, 6, 90. [CrossRef] [PubMed]

125. Benes, F.M.; Lim, B.; Subburaju, S. Site-specific regulation of cell cycle and DNA repair in post-mitotic GABA cells in schizophrenic versus bipolars. Proc. Natl. Acad Sci. USA 2009, 106, 11731-11736. [CrossRef] [PubMed]

126. Magin, G.K.; Robison, S.H.; Breslin, N.; Wyatt, R.J.; Alexander, R.C. DNA repair and mutant frequency in schizophrenia. Mutat. Res. 1991, 255, 241-246. [CrossRef]

127. Psimadas, D.; Messini-Nikolaki, N.; Zafiropoulou, M.; Fortos, A.; Tsilimigaki, S.; Piperakis, S.M. DNA damage and repair efficiency in lymphocytes from schizophrenic patients. Cancer Lett. 2004, 204, 33-40. [CrossRef] [PubMed]

128. Young, J.; McKinney, S.B.; Ross, B.M.; Wahle, K.W.J.; Boyle, S.P. Biomarkers of oxidative stress in schizophrenic and control subjects. Prostaglandins Leukot. Essent. Fatty Acids 2007, 76, 73-85. [CrossRef] [PubMed]

129. Catts, V.S.; Catts, S.V.; Jablensky, A.; Chandler, D.; Weickert, C.S.; Lavin, M.F. Evidence of aberrant DNA damage response signalling but normal rates of DNA repair in dividing lymphoblasts from patients with schizophrenia. World J. Biol. Psychiatry 2012, 13, 114-125. [CrossRef] [PubMed]

130. Arrieta, I.; Núñez, T.; Martínez, B.; Pérez, A.; Télez, M.; Criado, B.; Gainza, I.; Lostao, C.M. Chromosomal fragility in a behavioral disorder. Behav. Genet. 2002, 32, 397-412. [CrossRef] [PubMed]

131. Main, P.A.E.; Thomas, P.; Angley, M.T.; Young, R.; Esterman, A.; King, C.E.; Fenech, M.F. Lack of evidence for genomic instability in autistic children as measured by the cytokinesis-block micronucleus cytome assay. Autism. Res. 2015, 8, 94-104. [CrossRef] [PubMed]

132. Main, P.A.E.; Thomas, P.; Esterman, A.; Fenech, M.F. Necrosis is increased in lymphoblastoid cell lines from children with autism compared with their non-autistic siblings under conditions of oxidative and nitrosative stress. Mutagenesis 2013, 28, 475-484. [CrossRef] [PubMed]

133. Bjørge, M.D.; Hildrestrand, G.A.; Scheffler, K.; Suganthan, R.; Rolseth, V.; Kuśnierczyk, A.; Rowe, A.D.; Vågbø, C.B.; Vetlesen, S.; Eide, L.; et al. Synergistic actions of Ogg1 and mutyh DNA glycosylases modulate anxiety-like behavior in mice. Cell Rep. 2015, 13, 2671-2678. [CrossRef] [PubMed]

134. Regnell, C.E.; Hildrestrand, G.A.; Sejersted, Y.; Medin, T.; Moldestad, O.; Rolseth, V.; Krokeide, S.Z.; Suganthan, R.; Luna, L.; Bjørås, M.; et al. Hippocampal adult neurogenesis is maintained by Neil3-dependent repair of oxidative DNA lesions in neural progenitor cells. Cell Rep. 2012, 2, 503-510. [CrossRef] [PubMed]

135. Arguello, P.A.; Gogos, J.A. Modeling madness in mice: One piece at a time. Neuron 2006, 52, $179-196$. [CrossRef] [PubMed]

136. Meyer, U.; Feldon, J.; Fatemi, S.H. In-vivo rodent models for the experimental investigation of prenatal immune activation effects in neurodevelopmental brain disorders. Neurosci. Biobehav. Rev. 2009, 33, 1061-1079. [CrossRef] [PubMed]

137. Peleg-Raibstein, D.; Feldon, J.; Meyer, U. Behavioral animal models of antipsychotic drug actions. Handb. Exp. Pharmacol. 2012, 361-406.

138. Lee, Y.; Katyal, S.; Li, Y.; El-Khamisy, S.F.; Russell, H.R.; Caldecott, K.W.; McKinnon, P.J. The genesis of cerebellar interneurons and the prevention of neural DNA damage require XRCC1. Nat. Neurosci. 2009, 12, 973-980. [CrossRef] [PubMed]

139. Parsons, J.L.; Tait, P.S.; Finch, D.; Dianova, I.I.; Allinson, S.L.; Dianov, G.L. CHIP-mediated degradation and DNA damage-dependent stabilization regulate base excision repair proteins. Mol. Cell 2008, 29, 477-487. [CrossRef] [PubMed]

140. Markkanen, E.; Fischer, R.; Ledentcova, M.; Kessler, B.M.; Dianov, G.L. Cells deficient in base-excision repair reveal cancer hallmarks originating from adjustments to genetic instability. Nucleic Acids Res. 2015, 43, 3667-3679. [CrossRef] [PubMed]

141. Tebbs, R.S.; Flannery, M.L.; Meneses, J.J.; Hartmann, A.; Tucker, J.D.; Thompson, L.H.; Cleaver, J.E.; Pedersen, R.A. Requirement for the Xrcc1 DNA base excision repair gene during early mouse development. Dev. Biol. 1999, 208, 513-529. [CrossRef] [PubMed] 
142. Harrison, P.J. The hippocampus in schizophrenia: A review of the neuropathological evidence and its pathophysiological implications. Psychopharmacology 2004, 174, 151-162. [CrossRef] [PubMed]

143. Hampson, D.R.; Blatt, G.J. Autism spectrum disorders and neuropathology of the cerebellum. Front. Neurosci. 2015, 9, 420. [CrossRef] [PubMed]

144. Lewis, D.A.; Hashimoto, T.; Volk, D.W. Cortical inhibitory neurons and schizophrenia. Nat. Rev. Neurosci. 2005, 6, 312-324. [CrossRef] [PubMed]

145. Blatt, G.J.; Fatemi, S.H. Alterations in GABAergic biomarkers in the autism brain: Research findings and clinical implications. Anat. Rec. 2011, 294, 1646-1652. [CrossRef] [PubMed]

146. Gonzalez-Burgos, G.; Fish, K.N.; Lewis, D.A. GABA neuron alterations, cortical circuit dysfunction and cognitive deficits in schizophrenia. Neural Plast. 2011, 2011, 723184. [CrossRef] [PubMed]

147. Lewis, D.A.; Curley, A.A.; Glausier, J.R.; Volk, D.W. Cortical parvalbumin interneurons and cognitive dysfunction in schizophrenia. Trends Neurosci. 2012, 35, 57-67. [CrossRef] [PubMed]

(C) 2016 by the authors; licensee MDPI, Basel, Switzerland. This article is an open access article distributed under the terms and conditions of the Creative Commons Attribution (CC-BY) license (http://creativecommons.org/licenses/by/4.0/). 